\title{
EVALUATION OF GROWTH AND BIOACCUMULATION OF COBALT IN DIFFERENT TISSUES OF COMMON CARP, CYPRINUS CARPIO (ACTINOPTERYGII: CYPRINIFORMES: CYPRINIDAE), FED COBALT-SUPPLEMENTED DIETS
}

\author{
Sanjukta MUKHERJEE and Anilava KAVIRAJ* \\ Department of Zoology, University of Kalyani, Kalyani WB, India
}

\begin{abstract}
Mukherjee S., Kaviraj A. 2009. Evaluation of growth and bioaccumulation of cobalt in different tissues of common carp, Cyprinus carpio (Actinopterygii: Cypriniformes: Cyprinidae), fed cobalt-supplemented diets. Acta Ichthyol. Piscat. 39 (2): 87-93.
\end{abstract}

\begin{abstract}
Background. Cobalt (Co) is an essential mineral required in trace quantity in the diet of fish. Although freshwater fish are capable of accumulating adequate quantity of trace minerals from the medium, Co is extremely scarce in the freshwater resources. Therefore, freshwater fish require a supplement of Co in the diet. Since information regarding requirement of $\mathrm{Co}$ for growth and its balance in the body of fish is poorly documented there is scope to quantify requirement of cobalt for common carp.
\end{abstract}

Materials and Methods. Two separate trials were made with fingerlings of common carp, Cyprinus carpio: a growth trial made in outdoor cement tanks for 60 days and a digestibility trial made in $15-\mathrm{L}$ glass aquaria in the laboratory for 7 days. Four experimental diets (average crude protein 30.94\%) supplemented by four different levels of $\mathrm{Co}(0.00 \%, 0.05 \%, 0.10 \%$, and $1.0 \%)$ were formulated and tested in these two trials. Growth was evaluated from gain in weight, specific growth rate, feed conversion ratio, and deposition of protein and lipid in the body of the fish. Apparent protein digestibility (APD) of the diets was evaluated from the proportion of chromium $(\mathrm{Cr})$ and protein in the diet and faeces. Water qualities were checked every week and levels of Co in liver, kidney, gill, gut, and caudal trunk of the fish were determined by atomic absorption spectrophotometer at the end of 60 days in the growth trial.

Results. Fingerlings of $C$. carpio fed $0.1 \%$ to $1.0 \%$ cobalt-supplemented diet (CSD) showed significantly higher growth than the control diet. Although conversion rate, weight gain and SGR were significantly higher in $0.05 \%$ CSD as compared with control diet $(0.00 \% \mathrm{CSD})$, there was no significant difference in apparent protein digestibility (APD), apparent net protein utilization (ANPU), and deposition of crude protein in the body between fish fed control and $0.05 \%$ CSD. Fish fed $1.0 \%$ CSD showed significantly higher level of Co in different tissues as compared with other diet groups.

Conclusion. It is concluded from the present study that dietary supplement of $\mathrm{Co}(0.1 \%$ to $1.0 \%)$ serves as a growth promoter for common carp. Increased growth with no additional tissue burden of Co is achieved at $0.1 \%$ dietary Co, while a higher level of supplement (1.0\%) may result in increased deposition of Co in different tissues.

Keywords: fish, diet, cobalt, mineral, growth, bioaccumulation, Cyprinus carpio

\section{INTRODUCTION}

Cobalt $(\mathrm{Co})$ is one of the thirteen minerals that have been demonstrated to be essential components in the diet of fish (Davis and Gatlin 1991). Cobalt is a part of vita$\min B_{12}$ and is concerned with nitrogen assimilation, erythrocyte maturation and synthesis of haemoglobin (Ashley 1972, Hazell 1985). Intestinal microorganisms help to synthesize vitamin $B_{12}$ in fish, but removal of cobalt from the diet reduce intestinal synthesis of vitamin $\mathrm{B}_{12}$ (Lovell and Limsuwan 1982). Deficiency of vitamin $\mathrm{B}_{12}$ causes several abnormalities including poor appetite, poor growth, low haemoglobin, and anaemia in fish (Stickney 1994). Cobalt is thus essential for fish. Since freshwater fish are capable of absorbing minerals from the surrounding water in addition to the food ingested, the dietary requirement of a freshwater fish species for a particular element depends to a large extent on the concentration of the element in the medium (Hepher 1990).

But, Co is extremely scarce in freshwater bodies. While the concentration of Co ranges from $4-12 \mu \mathrm{g} \cdot \mathrm{L}^{-1}$ in the river water of Germany, it ranges from 1 to $36 \mu \mathrm{g} \cdot \mathrm{L}^{-1}$ in the rivers of USA (Barałkiewicz and Siepak 1999). KaradedeAkin and Ünlü (2007) detected trace to $0.08 \mathrm{mg} \cdot \mathrm{L}^{-1} \mathrm{Co}$ in the water in a section of the Tigris River in Turkey. In several other countries the uncontaminated natural waters have been found to contain no more than a few

\footnotetext{
* Correspondence: Dr Anilava Kaviraj, Department of Zoology, University of Kalyani, Kalyani-741235, West Bengal, India, phone (office): +9133-25828478, fax: +9133-25828282, e-mail: anilava@vsnl.net or akaviraj@gmail.com
} 
micrograms per litre of Co (Anonymous 1991, Hem 1992). We did not find any report of Co in any river or other freshwater bodies in India. Cobalt was also not detected in the medium used in the present experiment. Because of these uncertainties of $\mathrm{Co}$ in the freshwater medium, freshwater fish requires a supplement of Co in the diet for its optimum growth. But there is little information regarding requirement of $\mathrm{Co}$ for growth and its balance in the body of fish (Hasan 2000). Although animal and plant feed stuff used in the artificial feed formulation generally provide an adequate quantity of minerals (Gatlin and Wilson 1986, Jahan et al. 2000, Storebakken et al. 2000) some species of fish require additional supply of some minerals for optimum growth (Lorentzen and Maage 1999). There is evidence that fish reared with cobalt supplemented diet show significant increase in growth over fish fed control diets with no supplement of Co (Anadu et al. 1990, Hossein et al. 2008).

However, requirement of a metal in the diet of fish needs to be carefully screened to ensure that the metal is not accumulated in unnecessarily high level and elicits toxicological effects. A deficiency of micronutrients may result in increased accumulation of heavy metals from the environ- ment (Golovanova 2008). Kidney, liver, gill, and gut tissues are the principal sites of heavy metal accumulation in fish (Popov et al. 2002, Farkas et al. 2003). Co is also accumulated in the soft tissues of fish (Bird et al. 1999). However, accumulation of Co from diet and its distribution in different tissues of carp are not precisely known. The objective of the present study was to evaluate if dietary supplement of Co could increase the growth of common carp (Cyprinus carpio) and to determine accumulation of $\mathrm{Co}$ in different tissues in response to different levels of dietary Co.

\section{MATERIALS AND METHODS}

Two different trials were made with the fingerlings of Cyprinus carpio: a growth trial and a digestibility trial. Fingerlings of the fish (average length: $45.39 \pm 2.75 \mathrm{~mm}$; average weight: $1.02 \pm 0.26 \mathrm{~g}$ ) were collected from a local hatchery (Malakshmi Matshya Industries, Kalna, West Bengal) and were stocked in 50-L glass aquaria containing tap water (temperature $29.0 \pm 0.2^{\circ} \mathrm{C} ; \mathrm{pH}: 7.5 \pm 0.1$, DO: $7.7 \pm 0.2 \mathrm{mg} \cdot \mathrm{L}^{-1}$, total alkalinity: $70.8 \pm 3.8 \mathrm{mg} \cdot \mathrm{L}^{-1}$ as $\mathrm{CaCO}_{3}$ ). The fish were acclimatized in this condition for one week before using in any trial. During acclimati-

Table 1

Ingredient and proximate composition of the experimental diets

\begin{tabular}{|c|c|c|c|c|}
\hline \multirow{2}{*}{$\begin{array}{l}\text { Ingredient } \\
{[\%]}\end{array}$} & \multicolumn{4}{|c|}{ Diets (\% Co as supplement) } \\
\hline & $\mathrm{T} 1(0.00)$ & $\mathrm{T} 2(0.05)$ & $\mathrm{T} 3(0.10)$ & $\mathrm{T} 4(1.00)$ \\
\hline Rice bran & 10.57 & 10.57 & 10.57 & 10.57 \\
\hline Wheat flour & 21.14 & 21.14 & 21.14 & 21.14 \\
\hline Mustard oil cake & 42.29 & 42.29 & 42.29 & 42.29 \\
\hline Fishmeal & 22 & 22 & 22 & 22 \\
\hline Vitamin premix $^{1}$ & 2 & 2 & 2 & 2 \\
\hline Mineral premix ${ }^{2}$ & 2 & 2 & 2 & 2 \\
\hline $\mathrm{CoCl}_{2} \cdot 6 \mathrm{H}_{2} \mathrm{O}^{3}$ & 0 & 0.2 & 0.4 & 4.04 \\
\hline $\mathrm{CMC}^{4}$ & 0.5 & 0.5 & 0.5 & 0.5 \\
\hline $\mathrm{Cr}_{2} \mathrm{O}_{3}{ }^{5}$ & 0.1 & 0.1 & 0.1 & 0.1 \\
\hline \multicolumn{5}{|c|}{ Proximate composition $\left[\mathrm{g} \cdot \mathrm{kg}^{-1}\right.$ dry matter basis] } \\
\hline Dry matter & 900.0 & 897.9 & 890.0 & 888.0 \\
\hline Ash & 160.0 & 150.0 & 155.0 & 170.0 \\
\hline Moisture & 100.0 & 102.1 & 110.0 & 112.0 \\
\hline Crude protein & 313.0 & 312.0 & 311.7 & 300.9 \\
\hline Crude fat & 40.1 & 39.4 & 38.8 & 37.5 \\
\hline
\end{tabular}

${ }^{1}$ Contains [\%]: (Ambiplex; Brihans Lab, Pune): vitamin $\mathrm{B}_{1}: 7.14$, vitamin $\mathrm{B}_{2}: 2.55$, vitamin $\mathrm{B}_{6}: 1.02$, vitamin $\mathrm{B}_{12}$ : 0.012, biotin: 0.025 , calcium pantothenate: 2.55 , niacin: 76.50 , cholin chloride $\left(\mathrm{B}_{4}\right): 10.20$.

${ }^{2}$ Contains [\%]: calcium lactate (1.71), $\mathrm{CaSO}_{4} \cdot 2 \mathrm{H}_{2} \mathrm{O}(13.65), \mathrm{CaCl}_{2} \cdot 2 \mathrm{H}_{2} \mathrm{O}(68.13), \mathrm{KH}_{2} \mathrm{PO}_{4}(04.26), \mathrm{KCl}(03.75)$, $\mathrm{NaCl}$ (04.44), $\mathrm{Na}_{2} \mathrm{CO}_{3}$ (01.02), $\mathrm{MgSO}_{4} \cdot 7 \mathrm{H}_{2} \mathrm{O}(01.71), \mathrm{FeSO}_{4} \cdot 7 \mathrm{H}_{2} \mathrm{O}(0.68), \mathrm{ZnSO}_{4}(0.03), \mathrm{KI}(0.55), \mathrm{MnSO}_{4}(0.07)$.

${ }^{3}$ Used as source of dietary cobalt [g per $100 \mathrm{~g}$ diet].

${ }^{4}$ Carboxymethyl cellulose used [g per $100 \mathrm{~g}$ diet] as binder.

${ }^{5}$ Used as a non-absorbent reference substance only in the diets used in the digestibility experiments. 
zation, the fish were fed ad libitum a diet containing 30\% crude protein. The acclimatized fingerlings were stocked in outdoor tanks at a stocking density of forty fingerlings per tank.

Experimental diets were prepared with raw ingredients such as mustard oil cake, rice bran, fishmeal and wheat flour and were formulated to contain approximately $30.94 \%$ crude protein (Table 1 ). The prepared diet also contained trace amount of Co $\left(7.48 \pm 0.04 \mu \mathrm{g} \cdot \mathrm{g}^{-1}\right)$ before supplementation of the diet by the metal. Cobalt (II) chloride, hexahydrate was added in required quantity to the prepared diet to make four experimental diets with four different levels of dietary cobalt: $0.0 \%$ (T1), $0.05 \%$ (T2), $0.10 \%$ (T3), and $1.00 \%$ (T4) (Table 1). To test protein digestibility of the diets, $1.0 \%$ chromic oxide $\left(\mathrm{Cr}_{2} \mathrm{O}_{3}\right)$ was added to each diet separately. All diets were prepared in pelleted form using $0.5 \%$ carboxymethyl cellulose as a binder and the pellets were sun-dried for a few days before use in the trial.

The growth trial was made in 400-L outdoor cement tanks. Each tank was stocked with 40 acclimatized fingerlings. Altogether twelve tanks were arranged according to randomized block design so that fingerlings could be reared in three replicates for each of the four dietary conditions (Table 1). The fish were fed twice daily at an interval of eight hours at a fixed ration of $5 \%$ of the body weight. Samples of fish were bulk weighed every fortnight and the quantity of the feed required for each tank was readjusted. Samples of water were collected every week to determine water quality parameters. All fish from each outdoor tank were sampled at the end of 60-day trial; length $(\mathrm{mm})$ and weight $(\mathrm{g})$ of the fish were recorded and five sampled fish from each tank were subjected to biochemical analyses to determine moisture, crude protein, lipid and ash content $\left(\mathrm{g} \cdot \mathrm{kg}^{-1}\right.$ wet weight basis) of the fish. Percent increase in weight, specific growth rate (SGR \% per day), feed conversion ratio (FCR), protein efficiency ratio (PER), and apparent net protein utilization (ANPU \%) were calculated using standard methods (Steffens 1989).

The digestibility trial was conducted in 15-L glass aquaria. Each aquarium was stocked with 10 fish. The fish were fed a ration at $5 \%$ of their body weight. The ration was provided at $0800 \mathrm{~h}$ and the fish were allowed to eat for $6 \mathrm{~h}$. Left over diets were collected after $6 \mathrm{~h}$ of feeding, oven-dried, and weighed. The leaching rate was estimated by placing weighed diets in aquaria without fish for $6 \mathrm{~h}$ and then recollecting, drying and re-weighing the diets. The average leaching rate was used to calibrate the amount of uneaten diets. Faecal samples were collected by siphoning from each aquarium continuously at a 3-4 h interval for a period of $17 \mathrm{~h}$ after the removal of uneaten diets. To minimize nutrient leaching, only fresh and intact faeces were collected and dried to a constant weight at $60^{\circ} \mathrm{C}$ in an oven. Apparent protein digestibility (APD \%) of the diet was calculated from the proportion of $\mathrm{Cr}$ and protein in the diet and faeces following the methods described by Ellestad et al. (2002) and Mondal et al. (2008).

Chemical analyses and data collection. Proximate analyses of the experimental diets were performed following the AOAC procedures (Helrich 1990) as follows: moisture was determined by oven drying at $105^{\circ} \mathrm{C}$ for $24 \mathrm{~h}$; crude protein (Nitrogen *6.25) was determined by micro-Kjeldahl digestion; total lipid was determined by extracting the residue with $40-60^{\circ} \mathrm{C}$ petroleum ether for $7-8 \mathrm{~h}$ in a Soxhlet apparatus and ash was determined by ignition at $550^{\circ} \mathrm{C}$ in a Muffle furnace to a constant weight. Concentration of $\mathrm{Co}$ in the tissues, and $\mathrm{Cr}$ in the diets and faeces were determined by flame atomic absorption spectrophotometer (Varian Spectra AA240) located in the

Table 2

Digestibility and growth of common carp, Cyprinus carpio, fingerlings fed cobalt-supplemented diets

\begin{tabular}{lrrrr}
\hline Parameter & \multicolumn{1}{c}{ T1 } & \multicolumn{1}{c}{ T2 } & \multicolumn{1}{c}{ T3 } & T4 \\
\hline Initial weight [g] & $1.02 \pm 0.26$ & $1.02 \pm 0.26$ & $1.02 \pm 0.26$ & $1.02 \pm 0.26$ \\
Gain in weight [\%] & $72.99 \pm 2.94^{\mathrm{a}}$ & $85.30 \pm 3.43^{\mathrm{b}}$ & $84.38 \pm 3.31^{\mathrm{b}}$ & $108.57 \pm 10.31^{\mathrm{c}}$ \\
$\mathrm{APD}^{1}[\%]$ & $84.11 \pm 0.71^{\mathrm{a}}$ & $83.57 \pm 1.55^{\mathrm{a}}$ & $88.91 \pm 1.01^{\mathrm{b}}$ & $90.93 \pm 0.13^{\mathrm{c}}$ \\
FCR $^{2}$ & $2.97 \pm 0.03^{\mathrm{a}}$ & $2.70 \pm 0.09^{\mathrm{b}}$ & $2.58 \pm 0.11^{\mathrm{b}}$ & $2.12 \pm 0.24^{\mathrm{c}}$ \\
$\mathrm{SGR}^{3}[\%$ per d] & $0.39 \pm 0.01^{\mathrm{a}}$ & $0.44 \pm 0.02^{\mathrm{b}}$ & $0.45 \pm 0.03^{\mathrm{b}}$ & $0.52 \pm 0.02^{\mathrm{c}}$ \\
PER $^{4}$ & $2.15 \pm 0.09^{\mathrm{a}}$ & $2.59 \pm 0.10^{\mathrm{b}}$ & $2.64 \pm 0.10^{\mathrm{b}}$ & $3.50 \pm 0.33^{\mathrm{c}}$ \\
ANPU $^{5}[\%]$ & $18.38 \pm 0.74^{\mathrm{a}}$ & $22.73 \pm 1.52^{\mathrm{a}}$ & $28.13 \pm 3.13^{\mathrm{b}}$ & $29.03 \pm 3.23^{\mathrm{b}}$ \\
\hline
\end{tabular}

Data are mean $\pm \mathrm{SD}(n=10)$; means with dissimilar superscripts in the same row indicates least significant difference (LSD) between the means at 5\% level.

${ }^{1}$ APD $($ Apparent Protein Digestibility $)=100-100 \times((\%$ Cr in diet $/ \%$ Cr in faeces $) \times(\%$ protein in faeces $/ \%$ protein in diet $)$.

${ }^{2}$ FCR (Feed Conversion Ratio) $=$ dry weight of diet given / increase in weight of the fish.

${ }^{3}$ SGR $($ Specific Growth Rate $)=\{($ ln final weight $-\ln$ initial weight $) /$ days on trial $\} \times 100$.

${ }^{4}$ PER (Protein Efficiency Ratio) = wet weight gain of fish / protein consumed.

${ }^{5}$ ANPU (Apparent Net Protein Utilization $)=($ net increase in carcass protein / amount of protein consumed $) \times 100$. 
Department of Zoology, University of Kalyani. Detailed analytical procedures of the determination have been followed from Saha and Gilbreath (1991), Kaviraj and Ghosal (1998), and Guhathakurta and Kaviraj (2000). Water quality parameters in the experimental tanks were checked following standard procedures of APHA (Anonymous 1995).

Statistical analyses. One sample $\mathrm{K}-\mathrm{S}$ test revealed that all sets of data from both the trials were normally distributed. Therefore, these data were subject to one-way ANOVA, without any transformation, followed by least significant difference (LSD) test between the mean values to determine significant variation between the dietary levels (Gomez and Gomez 1984). The data have been presented in the tables as mean $\pm \mathrm{SD}$.

\section{RESULTS}

Fingerlings of Cyprinus carpio fed cobalt-supplemented diet (CSD) showed significantly higher growth than the control diet (Table 2). This was evident from weight gain, feed conversion ratio (FCR), and specific growth rate (SGR). Results of one-way ANOVA carried out on these parameters, with treatment and error degrees of freedom respectively as 3 and $8\left(\mathrm{df}_{3,8}\right)$, revealed that $F$ value calculated for each of this parameter was higher than the corresponding tabular value of $F(8.84)$ at $5 \%$ level of probability indicating significant variation between the dietary groups. Values of $F$ calculated for protein efficiency ratio (PER), apparent protein digestibility (APD), apparent net protein utilization (ANPU) and deposition of protein and lipid in the body of the fish also showed significant variation $(P<0.05)$ between the dietary groups. Comparing mean values of these parameters between the dietary groups by least significant difference (LSD) test it was revealed that growth was significantly higher in fish fed 1.0\% CSD (T4) as compared with $0.05 \%$ to $0.10 \% \mathrm{CSD}(\mathrm{T} 2-\mathrm{T} 3)$. Protein efficiency ratio (PER) also showed a similar trend. Apparent net protein utilization (ANPU) by the fish was similar between control (T1) and $0.05 \%$ CSD (T2) (LSD; $P>0.05$ ). But ANPU significantly increased in T3 and T4 diets as compared with T1 and T2 diets (LSD; $P<0.05$ ). Apparent protein digestibility (APD) of the $0.05 \%$ CSD diet (T2) was also similar to control (T1). APD increased significantly in $0.1 \%$ (T3) and $1.0 \%$ (T4) CSD as compared with control (T1) and $0.05 \%$ (T2) CSD. APD was significantly higher in T4 diet than T3 diet. However, ANPU was not significantly different between T3 and T4 diets.

The proximate composition of the carcass at the end of the trial showed a significant increase in crude protein level from the initial value in all the dietary groups ( $\mathrm{T} 1$ to T4; Table 3). The increase was significantly higher (LSD, $P<0.05)$ in T3 and T4 diets as compared with control (T1). Crude protein level of control and $0.05 \%$ CSD was similar (LSD, $P>0.05$ ). Crude lipid level of the body, however, significantly increased only in cobalt-supplemented diets (T2 to T4). There was no significant difference in ash content of the body between initial and final values of any diet group.

Bioaccumulation of cobalt $(\mathrm{Co})$ in different tissues of C. carpio has been included in Table 4. Co accumulation increased in all tissues as compared with the respective

Table 3

Proximate composition of carcass $\left[\mathrm{g} \cdot \mathrm{kg}^{-1}\right.$ wet weight basis] of common carp, Cyprinus carpio

\begin{tabular}{|c|c|c|c|c|c|}
\hline \multirow{2}{*}{ Component } & \multirow[t]{2}{*}{ Initial } & \multicolumn{4}{|c|}{ Final } \\
\hline & & $\mathrm{T} 1$ & $\mathrm{~T} 2$ & $\mathrm{~T} 3$ & $\mathrm{~T} 4$ \\
\hline Crude protein & $65.00 \pm 3.54^{\mathrm{a}}$ & $96.30 \pm 1.77^{b}$ & $102.50 \pm 3.54^{\mathrm{bc}}$ & $110.00 \pm 7.07^{\mathrm{c}}$ & $110.00 \pm 7.07^{\mathrm{c}}$ \\
\hline Crude lipid & $51.47 \pm 0.81^{\mathrm{a}}$ & $56.13 \pm 0.96^{\mathrm{ab}}$ & $60.51 \pm 1.83^{\mathrm{bc}}$ & $63.41 \pm 3.98^{c}$ & $63.22 \pm 0.19^{c}$ \\
\hline Ash & $101.38 \pm 17.32^{\mathrm{a}}$ & $94.32 \pm 16.51^{\mathrm{a}}$ & $93.38 \pm 13.08^{a}$ & $88.34 \pm 3.63^{\mathrm{a}}$ & $80.75 \pm 9.41^{\mathrm{a}}$ \\
\hline
\end{tabular}

Data are mean values $\pm \mathrm{SD}(n=5)$; different superscript letters in a row indicate significant difference between mean values (LSD, $P<0.05$ ).

Table 4

Level of Co $\left[\mu \mathrm{g} \cdot \mathrm{g}^{-1}\right.$ dry weight $]$ in different tissues of fish sampled at the end of experiment

\begin{tabular}{lccccc}
\hline Dietary group & Liver & Kidney & Gill & Gut & Caudal trunk \\
\hline Initial & - & - & - & - & $0.44 \pm 0.09^{\mathrm{a}}$ \\
$\mathrm{T} 1$ & $3.44 \pm 0.60^{\mathrm{a}}$ & $9.42 \pm 0.06^{\mathrm{a}}$ & $2.08 \pm 0.14^{\mathrm{a}}$ & $6.65 \pm 0.12^{\mathrm{a}}$ & $8.94 \pm 1.68^{\mathrm{b}}$ \\
$\mathrm{T} 2$ & $2.81 \pm 0.33^{\mathrm{a}}$ & $7.19 \pm 1.10^{\mathrm{a}}$ & $3.07 \pm 0.39^{\mathrm{b}}$ & $2.63 \pm 1.03^{\mathrm{a}}$ & $4.44 \pm 0.09^{\mathrm{b}}$ \\
$\mathrm{T} 3$ & $10.63 \pm 8.93^{\mathrm{ab}}$ & $10.63 \pm 0.29^{\mathrm{a}}$ & $1.89 \pm 0.03^{\mathrm{a}}$ & $3.97 \pm 0.68^{\mathrm{a}}$ & $5.19 \pm 0.09^{\mathrm{b}}$ \\
$\mathrm{T} 4$ & $17.50 \pm 3.76^{\mathrm{b}}$ & $31.21 \pm 7.37^{\mathrm{b}}$ & $24.15 \pm 0.56^{\mathrm{c}}$ & $91.51 \pm 12.58^{\mathrm{b}}$ & $30.21 \pm 7.37^{\mathrm{c}}$ \\
\hline
\end{tabular}

Data are mean values $\pm \mathrm{SD}$; different superscript letters between the diets in a column indicate significant difference (LSD; $P<0.05$ ). 
initial values. Results of one-way ANOVA, using Co in liver, kidney, gill, gut, and caudal trunk as dependent variables, showed that there was significant variation of Co accumulation in these tissues between the dietary groups $(P<0.05)$. Comparing tissue accumulation of Co between different dietary groups by LSD test, it was revealed that Co accumulation significantly increased in all tissues (LSD; $P<0.05$ ) of fish fed 1.0\% CSD (T4) as compared with other dietary groups (T1, T2, T3), except similar values of $\mathrm{Co}$ in liver between T3 and T4 diets $(P>0.05)$. Co level in all tissues of fish fed T1 to T3 diets showed similarity $(P>0.05)$ except a marginally but significantly higher values of $\mathrm{Co}$ in gill tissues of fish fed T2 diet as compared with those fed $\mathrm{T} 1$ and $\mathrm{T} 3$ diets. Maximum accumulation of Co in fish fed $1.0 \%$ CSD (T4) was found in gut followed by kidney, caudal trunk, gill and liver.

Water quality parameters recorded during the trial (temperature $28.89-31.56^{\circ} \mathrm{C}$; $\mathrm{pH}$ 7.34-7.78; dissolved oxygen $7.03-8.15 \mathrm{mg} \cdot \mathrm{L}^{-1} ; \mathrm{NH}_{3}-\mathrm{N} 0.14-0.22 \mathrm{mg} \cdot \mathrm{L}^{-1} ; \mathrm{NO}_{3}-\mathrm{N}$ $0.03-0.05 \mathrm{mg} \cdot \mathrm{L}^{-1}$ ) were within the optimum ranges required for rearing common carp. Co could not be detected in water in control and $0.05 \%$ CSD group. Level of Co detected in water in $0.1 \%$ and $1.0 \%$ CSD group at the end of experiment was respectively $0.28 \pm 0.06 \mathrm{mg} \cdot \mathrm{L}^{-1}$ and $0.41 \pm 0.05 \mathrm{mg} \cdot \mathrm{L}^{-1}$.

\section{DISCUSSION}

Inadequate literature sources are available to quantify dietary requirement of cobalt for optimum growth of fish. While a few species like rainbow trout requires meagre amount of Co (0.05 $\mathrm{mg} \mathrm{Co} \cdot \mathrm{kg}^{-1}$ diet; Hasan 2000) effects of the mineral on growth of fish are not well established. Diets used for common carp in the present investigation contained $\mathrm{Co}$ in much higher level than those required by rainbow trout. This excess dietary cobalt increased the digestibility of the diets and growth of common carp. Digestibility was increased at inclusion level above $0.05 \%$ Co $(0.1 \%$ to $1.0 \%)$ while growth increased in all the levels of dietary Co tested $(0.05 \%$ to $1.0 \%)$. The results indicate that $\mathrm{Co}$ act as growth promoter for common carp. Growth promoting effects of Co has also been demonstrated for tilapia (Anadu et al. 1990) and rainbow trout (Hossein et al. 2008). Adhikari and Ayyappan (2002) observed that Indian major carp, Labeo rohita, exhibited significantly higher growth when cobalt was used as a micronutrient fertilizer. Common carp fed a fodder diet supplemented by $\mathrm{Co}$ at $3 \mathrm{~g}$ per ton (equivalent to $0.03 \%$ of diet) also showed an increase by 30 percentage points in growth of fingerlings and an average of 15-20 percentage-point increase in growth of two-year-old commercial fish (Sukhoverkhov 1967). Cobalt is an essential mineral necessary for the synthesis of vitamin $\mathrm{B}_{12}$. But only trace amount of $\mathrm{Co}$ is required for this purpose. Other physiological role of Co in fish has not yet been determined. Common carp fed cobalt-supplemented fodder exhibited an increase in erythrocyte count and haemoglobin content of the fish apart from increasing vitamin $B_{12}$ content in the liver of the fish (Sukhoverkhov 1967).
Hertz et al. (1989) observed that an increase in the level of $\mathrm{Co}$ in the diet of fish could increase incorporation of labelled amino acid into fish protein thereby promoting a protein sparing effect in the diet of fish. Therefore, excess dietary cobalt, as observed in the present investigation, can well act as growth promoter of fish.

The present study reveals that $\mathrm{Co}$ is accumulated in different tissues of common carp fed even the control diet with no dietary Co supplement indicating that ingredients used in the formulation of diet served as a source of Co. It is further revealed from the present study that an equilibrium of Co exists in the body of common carp even when $\mathrm{Co}$ is added to the diet up to inclusion level of $0.1 \%$ $\mathrm{Co}$ in the diet. Further increase in dietary Co significantly increased Co in all tissues. Accumulation of Co from diet and its distribution in different tissues of fish is poorly documented. Available literatures indicate that $\mathrm{Co}$ is accumulated from the medium at small concentration in some soft tissues of fish. In rainbow trout the metal has been found accumulated mainly in the kidney $\left(0.195-0.449 \mu \mathrm{g} \cdot \mathrm{g}^{-1}\right)$, blood $\left(0.038-0.090 \mu \mathrm{g} \cdot \mathrm{g}^{-1}\right)$, spleen $\left(0.015-0.078 \mu \mathrm{g} \cdot \mathrm{g}^{-1}\right)$, and liver $\left(0.015-0.068 \mu \mathrm{g} \cdot \mathrm{g}^{-1}\right)$ tissues of the fish (Harms and Kunze 1977). The skeletal and muscle tissue accumulated negligible quantity of the metal (0.007 to $0.014 \mu \mathrm{g} \cdot \mathrm{g}^{-1}$ and 0.002 to $0.007 \mu \mathrm{g} \cdot \mathrm{g}^{-1}$, respectively). Concentrations of $\mathrm{Co}$ in muscle, gill, and liver were, however, moderately higher (2.47-3.59, $8.28-10.1$, and $10.2-13.0 \mathrm{mg} \cdot \mathrm{kg}^{-1}$ dry mass) in Nile tilapia, Oreochromis niloticus (see: Kebede and Wondimu 2004) than rainbow trout. Concentration of Co in the medium was not mentioned in any of these two studies. But moderately high concentration of $\mathrm{Co}$ (4.03-4.06 $\mu \mathrm{g} \cdot \mathrm{g}^{-1}$ dry weight) detected in the muscle of tilapia was correlated to moderately high concentration of the Co $\left(70-96 \mu \mathrm{g} \cdot \mathrm{L}^{-1}\right)$ in the water of a lake (Ali and Fishar 2005). Deficiency in micronutrient concentration in the body of fish may result in increased accumulation of heavy metals notwithstanding concentration of the metal in the medium (Golovanova 2008). In the presently reported study Co could not be detected in the medium containing control and $0.05 \%$ CSD group. Co probably leached out from the higher CSDs and the level of Co moderately increased in water in these dietary groups $(0.1 \%$ and $1.0 \%)$. Since there was no apparent deficiency of Co in any diet (even in control) and Co was detected in water only in moderate level in the higher CSD groups it is assumed that Co was accumulated in different tissues of common carp principally from the diet. This was also evident from the very high level of Co detected in the gut tissues in $1.0 \%$ CSD group. Yildiz (2008) also observed significantly higher level of $\mathrm{Co}$ in fillet of fish cultured on diets containing $\mathrm{Co}$ as compared with those captured from the wild.

The presently reported study indicates that additional supply of Co up to $0.1 \%$ in the diet did not significantly increase the Co level in the tissues, except a marginal increase in gill, as compared with the control diet. Dietary inclusion of $\mathrm{Co}$ at $1.0 \%$ level however, significantly increased $\mathrm{Co}$ in all tissues. Although the increase in tissue 
level of Co did not affect the growth of fish, there is probability that average daily intake (ADI) of Co in man, which depends to a great extent on the food habit (Yamagata et al. 1963, Biego et al. 1998, Fakayode and Olu-Owolabi 2003), may increase through consumption of such fish. But, no safe recommended dietary allowance (RDA) has yet been established for cobalt, although a RDA for man is available for vitamin $\mathrm{B}_{12}(2.4 \mu \mathrm{g}$ per day) of which $\mathrm{Co}$ is an integral part (Anonymous 2009). Moreover, actual intake rate of Co in dressed fish after removal of the viscera could not be quantified in this study.

Therefore, it is concluded that dietary Co acts as growth promoter for common carp and formulation of diet with additional supply of Co is a viable option for augmentation of production of this fish. Increased growth with no additional tissue burden of $\mathrm{Co}$ is achieved at $0.1 \%$ dietary Co, while a higher level of supplement $(1.0 \%)$ may result in increased deposition of Co in different tissues.

\section{ACKNOWLEDGEMENTS}

The authors are thankful to the University of Kalyani for providing financial support for this research.

\section{REFERENCES}

Adhikari S., Ayyappan S. 2002. Fertilization of freshwater fish ponds with cobalt and its adsorption and desorption in the pond sediment. The Israeli Journal of AquacultureBamidgeh 54 (3): 110-115.

Ali M.H.H., Fishar M.R.A. 2005. Accumulation of trace metals in some benthic invertebrate and fish species relevant to their concentration in water and sediment of Lake Qarun, Egypt. Egyptian Journal of Aquatic Research 31: 289-301.

Anadu D.I., Anozie O.C., Anthony A.D. 1990. Growth responses of Tilapia zillii fed diets containing various levels of ascorbic acid and cobalt chloride. Aquaculture 88: 329-336. DOI: 10.1016/0044-8486(90)90158-J.

Anonymous 1991. IARC Monographs on the evaluation of carcinogenic risks of chemicals to humans. Vol. 52: chlorinated drinking water; chlorination by-products; some other halogenated compounds; cobalt and cobalt compounds. Pp. 363-472. International Agency For Research on Cancer, Lyon, France.

Anonymous 1995. Standard methods for the examination of water and wastewater. American Public Health Association, American Water Works Association and Water Pollution Control Federation, Washington, DC.

Anonymous 2009. Dietary supplement fact sheet: Vitamin $B_{12}$. Office of Dietary Supplements, National Institute of Health. http://ods.od.nih.gov/factsheets/vitaminB12.asp.

Ashley L.M. 1972. Nutritional pathology. Pp. 439-539. In: Halver J.E. (ed.) Fish Nutrition. Academic Press, New York.

Barałkiewicz D., Siepak J. 1999. Chromium, nickel and cobalt in environmental samples and existing legal norms. Polish Journal of Environmental Studies 8: 201-208.

Biego G.H., Joyeux M., Hartemann P., Debry G.1998. Daily intake of essential minerals and metallic micropollutants from foods in France. The Science of the Total Environment 217: 27-36. DOI: 10.1016/S0048-9697(98)00160-0.
Bird G.A., Mills K.H., Schwartz W.J. 1999. Accumulation of ${ }^{60} \mathrm{Co}$ and ${ }^{134} \mathrm{Cs}$ in lake whitefish in a Canadian Shield lake. Water Air and Soil Pollution 114: 303-322. DOI: 10.1023/A:1005146015822.

Davis A.D., Gatlin D.M.III. 1991. Dietary mineral requirements of fish and shrimp. Pp. 49-67. In: Akiyama D.M., Tan K.H. (eds.) Proceedings of the Aquaculture Feed Processing and Nutrition Workshop. American Soybean Association, Singapore.

Ellestad L.E., Angel R., Soares J.H. jr. 2002. Intestinal phytase II: a comparison of activity and in vivo phytate hydrolysis in three teleost species with differing digestive strategies. Fish Physiology and Biochemistry 26: 259-273. DOI: 10.1023/A:1026231624543.

Fakayode S.O., Olu-Owolabi I.B. 2003. Trace metal content and estimated daily human intake from chicken eggs in Ibadan, Nigeria. Archives of Environmental Health 58: 245-251. DOI: 10.3200/AEOH.58.4.245-251.

Farkas A., Salanki J., Specziar A. 2003. Age- and size-specific patterns of heavy metals in the organs of freshwater fish Abramis brama L. populating a low contaminated site. Water Research 37: 959-964. DOI: 10.1016/S0043-1354(02)00447-5.

Gatlin D.M.III., Wilson R.P. 1986. Characterization of iron deficiency and the dietary iron requirement of fingerling channel catfish. Aquaculture 52: 191-198. DOI: 10.1016/0044-8486(86)90143-2.

Golovanova I.L. 2008. Effects of heavy metals on the physiological and biochemical status of fishes and aquatic invertebrates. Inland Water Biology 1: 93-101. DOI: 10.1007/s12212-008-1014-1.

Gomez K.A., Gomez A.A. 1984. Statistical procedures for agricultural research. 2nd edn. John Wiley and Sons, New York.

Guhathakurta H., Kaviraj A. 2000. Heavy metal concentration in water, sediment, shrimp (Penaeus monodon) and mullet (Liza parsia) in some brackishwater ponds of Sunderban, India. Marine Pollution Bulletin 40: 914-920. DOI: 10.1016/S0025-326X(00)00028-X.

Harms U., Kunze J. 1977. Bestimmung von Kobalt in kleinen Gewebe- und Organproben der Regenbogenforelle (Salmo gairdneri) durch flammenlose Atom-AbsorptionsSpektroskopie. Zeitschrift für Lebensmitteluntersuchung und -Forschung A 164: 204-207.

Hasan M.R. 2000. Nutrition and feeding for sustainable aquaculture development in the third millennium. Pp. 193-219. In: Subasinghe R.P., Bueno P., Phillips M.J., Hough C., McGladdery S.E., Arthur J.R. (eds.) Aquaculture in the Third Millennium. Technical Proceedings of the Conference on Aquaculture in the Third Millennium, Bangkok, Thailand, 20-25 February 2000. NACA, Bangkok and FAO, Rome.

Hazell T. 1985. Minerals in foods: dietary sources, chemical forms, interactions, bioavailability. World Review of Nutrition and Dietetics 46: 1-123.

Helrich W. (ed.) 1990. Official methods of analyses. Vol. I. 15th edn. Association of Official Analytical Chemists, Washington, DC.

Hem J.D. 1992. Study and interpretation of the chemical char- 
acteristics of natural water. US Geological Survey WaterSupply Paper 2254, Washington, DC.

Hepher B. 1990. Nutrition of pond fishes. Cambridge University Press, Cambridge, UK.

Hertz Y., Madar Z., Hepher B., Gertler A. 1989. Glucose metabolism in the common carp (Cyprinus carpio L.): the effects of cobalt and chromium. Aquaculture 76: 255-267. DOI: 10.1016/0044-8486(89)90079-3.

Hossein E., Abbas M., Shohreh B. 2008. Effects of cobalt as growth promotant on the growth of rainbow trout, Oncorhynchus mykiss. P. 165. World Aquaculture 2008: Aquaculture for Human Wellbeing-The Asian Perspective; 19-23 May 2008; Busan, Korea.

Jahan P., Watanabe T., Satoh S., Kiron V. 2000. Effect of dietary fish meal levels on environmental phosphorus loading from carp culture. Fisheries Science 66: 204-210. DOI: 10.1046/j.1444-2906.2000.00036.x.

Karadede-Akin H., Ünlü E. 2007. Heavy metal concentrations in water, sediment, fish and some benthic organisms from Tigris River, Turkey. Environmental Monitoring and Assessment 131: 323-337. DOI: 10.1007/s10661-006-9478-0.

Kaviraj A., Ghosal T. K. 1998. Effects of compost manure on the body burden of cadmium and growth of common carp Cyprinus carpio (L). Aquaculture Research 29: 555-561. DOI: 10.1046/j.1365-2109.1998.00237.x.

Kebede A., Wondimu T. 2004. Distribution of trace elements in muscle and organs of tilapia, Oreochromis niloticus, from Lakes Awassa and Ziway, Ethiopia. Bulletin of the Chemical Society of Ethiopia 18: 119-130.

Lorentzen M., Maage A. 1999. Trace element status of juvenile Atlantic salmon Salmo salar L. fed a fishmeal based diet with or without supplementation of zinc, iron, manganese and copper from first feeding. Aquaculture Nutrition 5: 163-171. DOI: 10.1046/j.1365-2095.1999.00096.x.

Lovell R.T. and Limsuwan T. 1982. Intestinal synthesis and dietary nonessentiality of vitamin $\mathrm{B}_{12}$ for Tilapia nilotica. Transactions of the American Fisheries Society 111: 485-490. DOI: 10.1577/1548-8659(1982)111<485:ISAD$\mathrm{NO}>2.0 . \mathrm{CO} ; 2$.

Mondal K., Kaviraj A., Mukhopadhyay P.K. 2008. Evaluation of fermented fish-offal in formulated diet of the freshwater catfish Heteropneustes fossilis. Aquaculture
Research 39: 1443-1449. DOI: 10.1111/j.13652109.2008.02014.x.

Popov P.A., Androsova N.V., Anoshin G.N. 2002. [Accumulation and distribution of heavy and transient metals in the Novosibirsk reservoir fish.] Voprosy Ihtiologii 42: 264-270.

Saha D.C., Gilbreath R.L. 1991. Analytical recovery of chromium in diet and faeces determined by colorimetry and atomic absorption spectrophotometry. Journal of the Science of Food and Agriculture 55: 433-446. DOI: 10.1002/jsfa.2740550311.

Stickney R.R. 1994. Principles of aquaculture. John Wiley and Sons, New York.

Steffens W. 1989. Principles of fish nutrition. Ellis Horwood, Chichester.

Storebakken T., Shearer K.D., Roem A.J. 2000. Growth, uptake and retention of nitrogen and phosphorus, and absorption of other minerals in Atlantic salmon Salmo salar fed diets with fish meal and soy-protein concentrate as the main sources of protein. Aquaculture Nutrition 6: 103-108. DOI: 10.1046/j.1365-2095.2000.00135.x.

Sukhoverkhov F.M. 1967. The effect of cobalt, vitamins, tissue preparations and antibiotics on carp production. Pp. 400-407. In : Pillay T.V.R. (ed.) Proceedings of the FAO world symposium on warm-water pond fish culture. Rome, FAO Fisheries Reports No. 44, Vol. 3. III/E-7. http//www.fao.org/docrep/ /005/66573T/66573T33.htm.

Yamagata N, Kurioka W, Shimizu T. 1963. Balance of cobalt in Japanese people and diet. Journal of Radiation Research 4: $8-15$.

Yildiz M. 2008. Mineral composition in fillets of sea bass (Dicentrarchus labrax) and sea bream (Sparus aurata): a comparison of cultured and wild fish. Journal of Applied Ichthyology 24: 589-594. DOI: 10.1111/j.1439$-0426.2008 .01097 . x$.

Received: 23 November 2008

Accepted: 20 April 2009

Published electronically: 10 December 2009 